\title{
THE USE OF AHP METHOD FOR THE DETERMINATION OF THE MOST ENVIRONMENTALLY BENEFICIAL VARIANTS OF BARRAGES
}

\author{
Justyna Kubicz', Mateusz Hämmerling², Natalia Walczak² \\ 1 Institute of Environmental Engineering, Wroclaw University of Environmental and Life Sciences, Plac \\ Grunwaldzki 24, 50-363 Wrocław, Poland, e-mail: justyna.kubicz@up.wroc.pl \\ 2 Department of Hydraulic Engineering, Poznan University of Life Sciences, Piątkowska 94A, 60-649 Poznań, \\ Poland, e-mail:mhammer@up.poznan.pl; natwal@wp.pl
}

Received: 2015.07.14

Accepted: 2015.08.31

Published: 2015.10.01

\begin{abstract}
This study presents an attempt to apply the AHP (Analytic Hierarchy Process) method for the determination of the most beneficial concept of development of a barrage. The main focus of the analysis was the influence of the civil engineering structure on various elements of the environment. The AHP method was applied to analyse the influence of specific scenarios on environmental elements and on the overall objective. Basing on the analysis, local and global priorities were determined for individual elements of the created decision tree, which allowed us to select the most beneficial scenario. The scenarios referred to the existing hydraulic structures located on the rivers Głomia, Gwda and Prosna. In order to verify the obtained results, calculations of the consistency of the importance evaluations for specific criteria were performed.
\end{abstract}

Keywords: AHP method, environmental impact evaluation, hydraulic structure.

\section{INTRODUCTION}

Barrages on water courses are usually erected to serve several purposes: to dam water and to be used for power generation, for flood protection, to use water for business purposes or to increase depth for shipping. The selection of the appropriate variant of the constructed object that will meet the investor's expectations and at the same time will have the lowest environmental impact is a difficult and complex task. It requires the evaluation of numerous processes and conducting analyses. The evaluation of the environmental impact is very complex due to numerous issues that need to be taken into account. The most important ones include the influence of the structure on surface waters (changes in the physical and chemical properties of water, changes in the hydraulic conditions) and ground waters (change in the level of ground water), limiting the movement of sediment in the water course, influence on fauna and flora resulting from splitting the ecological corridor, changes in soil properties resulting from the transformations of soil and water conditions, influence the level of risk of flood and flooding of adjacent land or the changes in the microclimatic conditions in the area of the constructed object.

The selection of the optimal variant of a barrage in the water course is a multi-criteria dilemma, which makes it so difficult to solve. This study presents the main objectives of the AHP Analytic Hierarchy Process method and a sample of potential implementation of this method to solve the selected decision problem, i.e. the selection of the optimal variant of barrage for the environment.

\section{MATERIALS AND METHODS}

When analysing complex problems, the decision-making process focuses on weighing the options that fulfil a set of desired objectives. The decision consists in selecting one option from numerous possibilities [Adamus, Lask 2010). In order to facilitate the process, Thomas L. Saati de- 
veloped the Analytical Hierarchy Process (AHP) method in the 1970's. Numerous applications of this method in supporting economic, technical or social decisions confirm its usefulness, in particular in cases when the experience of the evaluator is the main source of assessment and a major part of the evaluation criteria is subjective. The AHP method is particularly useful in cases when the hierarchy of evaluation criteria represents various levels of specificity, most of these criteria are of a qualitative, not quantitative nature and the variants are fully comparable [Downarowicz et al., 2000].

The analysis of a problem with use of the AHP method consists of four steps [Downarowicz et al., 2000]. The first step involves the decomposition of the problem, i.e. the determination of the overall objective and drawing a tree illustrating the hierarchy of links between specific factors influencing the analysed problem. The tree is created starting from general criteria, which are then specified. The subsequent stage consists in the paired comparison of criteria and decision variants located on the same level of the event tree with respect to higher branches and assigning them adequate weights according to the scale developed by Saati (Table 1).

The third stage of analysis consists in the creation and solving of matrices basing on the obtained weights. A characteristic feature of matrices in the AHP method is the diagonal, which adopts constant values (1). The results of com-

Table 1. Weights according to Saati [pursuant to: Fabisiak, Ziemba 2011]

\begin{tabular}{|c|l|}
\hline $\begin{array}{c}\text { Numerical } \\
\text { score }\end{array}$ & \multicolumn{1}{|c|}{ Verbal score } \\
\hline 1 & $\begin{array}{l}\text { Comparable decision variants, criteria are } \\
\text { equivalent }\end{array}$ \\
\hline 2 & $\begin{array}{l}\text { The decision maker is hesitating between the } \\
\text { equivalence of the decisive criteria and a slight } \\
\text { advantage of the first object }\end{array}$ \\
\hline 3 & $\begin{array}{l}\text { Slight advantage of the first decision criterion } \\
\text { over the other }\end{array}$ \\
\hline 4 & $\begin{array}{l}\text { The decision maker is hesitating between slight } \\
\text { and large advantage of the first criterion over the } \\
\text { other one }\end{array}$ \\
\hline 5 & $\begin{array}{l}\text { Large advantage of the first decision criterion } \\
\text { over the other }\end{array}$ \\
\hline 6 & $\begin{array}{l}\text { The decision maker is hesitating between large } \\
\text { and significantly large advantage of the first } \\
\text { criterion over the other one }\end{array}$ \\
\hline 7 & $\begin{array}{l}\text { Significantly large advantage of the first object } \\
\text { over the other }\end{array}$ \\
\hline 9 & $\begin{array}{l}\text { The decision maker is hesitating between } \\
\text { significantly large and enormous advantage of } \\
\text { the first object over the other one }\end{array}$ \\
\hline Enormous advantage of the first object over the \\
other
\end{tabular}

parisons between specific criteria or scenarios are entered into the matrix above the diagonal. The values below the diagonal are the reciprocal of the values above the diagonal. Normalised rows of the matrix are totalled and the eigenvector (socalled priority vector) of the matrix is calculated. The higher the value of the priority vector, the more important the given element. In order to verify the reliability of the results of paired comparisons, conducted by experts, the eigenvalue of the comparison matrix $\lambda_{\text {sr, }}$ inconsistency ratio $I R$ and consistency index $C I$ are calculated.

$$
\lambda_{\text {s } r}=\frac{1}{n} \sum_{i=1}^{n} \lambda_{i}
$$

where: $n$ - size of the matrix,

$\lambda_{i}$ - eigenvalue of the matrix.

The further the $\lambda_{s r}$ diverges from the size of the matrix $n$, the larger the error.

$$
C I=\frac{n-\lambda_{\text {s } r}}{n-1}
$$

where: $R I$ - is the Random Consistency Index depending on the degree of the matrix, read basing on Table 2 .

The value of the inconsistency ratio $I R$ should not exceed 0.2 [Tułecki, Król 2007]. The next and at the same time the final step is the determination of global preferences along with the ranking and classification of decision variants based on previous calculations.

Three existing hydrological objects on the rivers Prosna, Głomia and Gwda were selected as models for scenarios. A brief characteristics of the model structures is presented below.

\section{Variant 1 of the analysis - Skórka barrage}

The Skórka barrage is located on $\mathrm{km} \mathrm{11+132}$ of the Głomia river, in the area of the commune Krajenka, Złotowski poviat, Wielkopolskie Voivodeship. The barrage consists of a three-span weir, a small hydraulic power plant, a fish pass and canoe pass (Figure 1). The structure belongs to the $4^{\text {th }}$ importance class [Franczak 2009].

The weir has a reinforced concrete dock structure of a width of $9 \mathrm{~m}$, with a practical shape barrage. The total length of the body is $14.0 \mathrm{~m}$. It consists of three $3 \mathrm{~m}$ wide spans, equipped with single-wing steel sliders with a manual tracking mechanism and maintenance flashboards. The divider pillars are $0.6 \mathrm{~m}$ thick, similarly to the abutments, ending with free-standing wings of Larssen sheet piles connecting the weir to the land. 
Table 2. Value of the random consistency index [Downarowicz et al., 2000]

\begin{tabular}{|c|c|c|c|c|c|c|c|}
\hline $\mathrm{n}$ & 2 & 3 & 4 & 5 & 6 & 7 & 8 \\
\hline $\mathrm{RI}$ & 0 & 0.58 & 0.90 & 1.12 & 1.24 & 1.32 & 1.41 \\
\hline
\end{tabular}

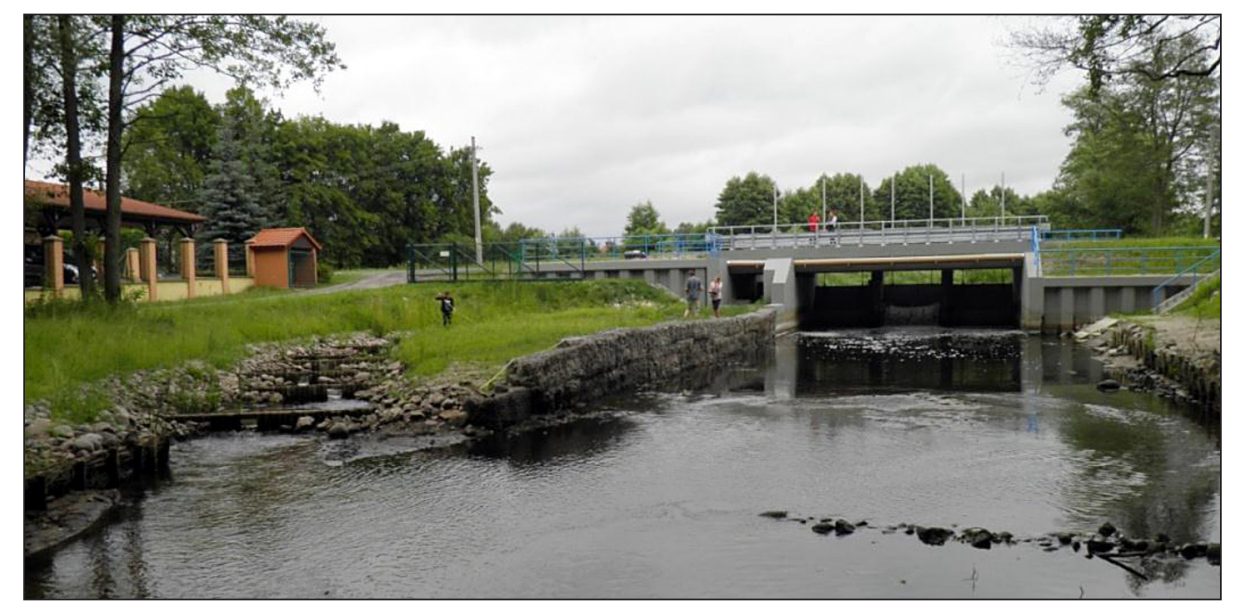

Figure 1. Skórka barrage on the Głomia river (photo by Authors)

The ordinate of the barrage is $78.30 \mathrm{~m}$ above sea level, while the ordinate of the bottom on the downstream position is $76.50 \mathrm{~m}$ above sea level. The bridge plate is $8 \mathrm{~m}$ wide, constructed from "Wagrowiec" type beams, with an asphalt concrete surface. On the upstream side the river bed is reinforced with $0.2 \mathrm{~m}$ thick concrete pates on a length of $5 \mathrm{~m}$. This reinforcement ends with a timber palisade. A similar reinforcement exists on the downstream site, with additional $0.3 \mathrm{~m}$ thick mesh and stone gabions. The small hydraulic power plant is located in the building of a former mill, on the right bank of the river, approx. $45 \mathrm{~m}$ from the weir abutment. It is a derivative power plant, located on the Młynski Channel.

The fish pass is located on the right-side bank of the river and the inlet, equipped with a steel slider, is situated next to the weir abutment. The object consists of 15 chambers, of which the first three ones, located on the upstream side below the bridge structure, are technical (Figure 2a). They are constructed in form of a reinforced concrete dock with a $2 \mathrm{~m}$ wide bottom of an inclination of $4 \%$ and are equipped with $0.2 \mathrm{~m}$ thick partitions with centrally placed, $0.3 \mathrm{~m}$ wide slots. Further chambers are constructed as a natural rapid of a trapezoidal cross-section (Figure 2b). The total length of the semi-natural part is approx. $40 \mathrm{~m}$. The river bed was reinforced with a riprap of irregularly placed stones of a varied diameter. The sizes of the chambers are quite irregular. The average chamber has a length of $3.5 \mathrm{~m}$, bottom width of $1.5 \mathrm{~m}$ and the slope inclination of ap- prox. 1:1.5. The partitions are palisades made from wooden dowels of a diameter of approx. 0.1 $\mathrm{m}$ with slots of the approx. width of $0.3 \mathrm{~m}$, located alternately on the right and left side. The fish pass structure has been separated from the actual river bed with a mesh and stone wall.

\section{Variant 2 of the analysis - Podgaje barrage}

The Gwda river was developed at the beginning of the $20^{\text {th }}$ century. 5 barrages were built at that time: Dobrzyca (1907), Podgaje (1929), Jastrowie (1930), Ptusza (1932), Koszyce (1936). Water is let through the barrage with the use of siphon overfalls and spillways with flat wooden closures as well as bottom sluices. In Podgaje, siphons constitute an integral part of the weir embedded in the body of the earth dam (Figure 3 ). In each of the siphon overfall sections of the Podgaje weir (Figure 4) 6 air vents are located on the side of the reservoir. Their task is to stop the operation of the siphon after the water level in the reservoir has been lowered to the ordinate corresponding to normal filling level.

In the hydraulic power plant in Podgaje (Figure 4) two Kaplan turbines are installed, of 2.2 MW power, installed flow rate $2 \times 14.5 \mathrm{~m}^{3 / \mathrm{s}}=29$ $\mathrm{m}^{3 /} \mathrm{s}$, and the average annual power generation is $6.1 \mathrm{GWh}$. The area of the reservoir created by the barrage covers $116 \mathrm{ha}$, and its total capacity amounts to 3.87 million $\mathrm{m}^{3}$. The average annual flow in the years $1982-2008$ was $10.39 \mathrm{~m}^{3 / \mathrm{s}}$. [Kubiak-Wójcicka, Muszyńska 2011]. 
a)

b)

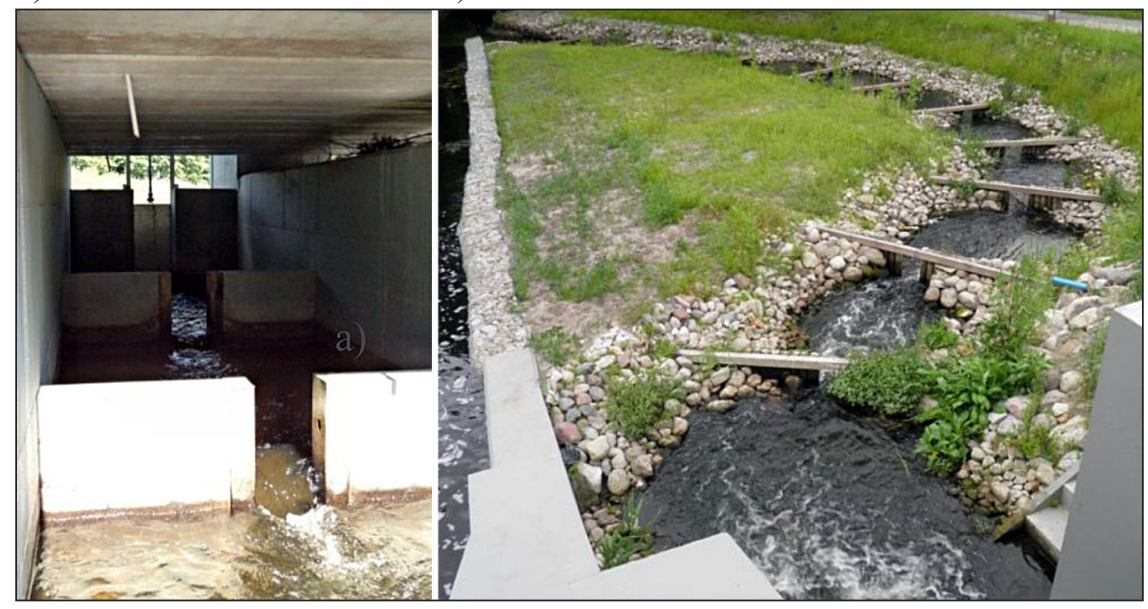

Figure 2. Fish pass on the Skórka barrage: a) technical part, b) semi-natural part (photo by Authors)

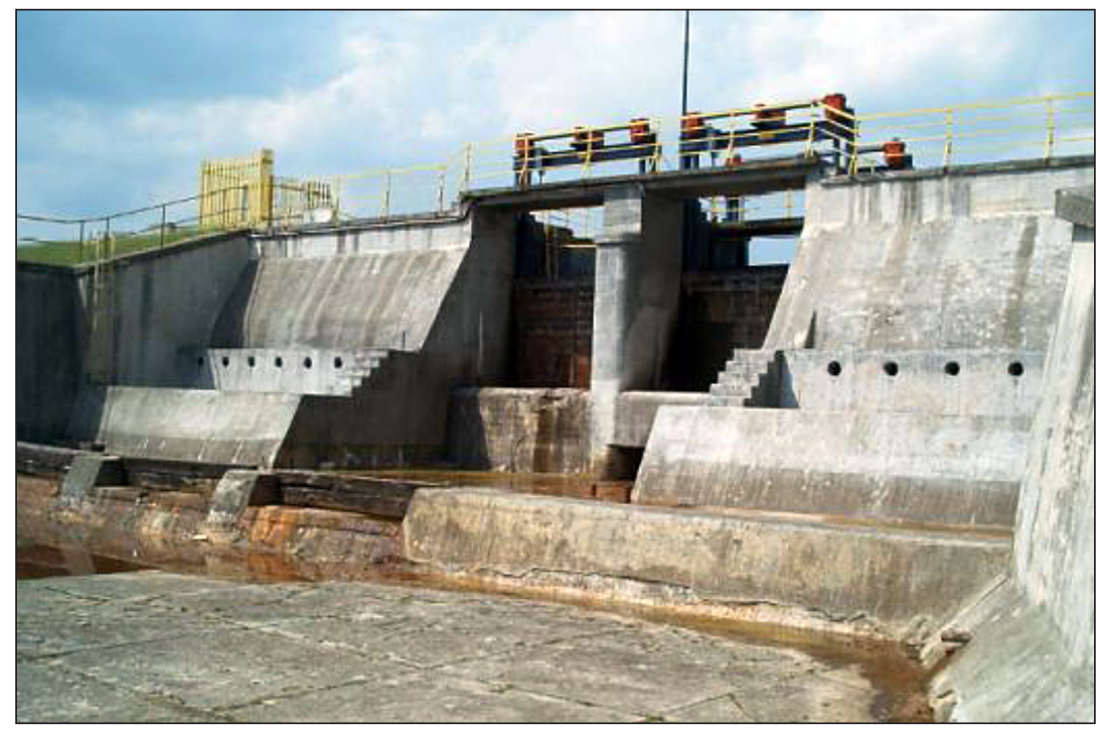

Figure 3. Podgaje weir [Sterpejkowicz-Wersocki and Bolt, 2002]

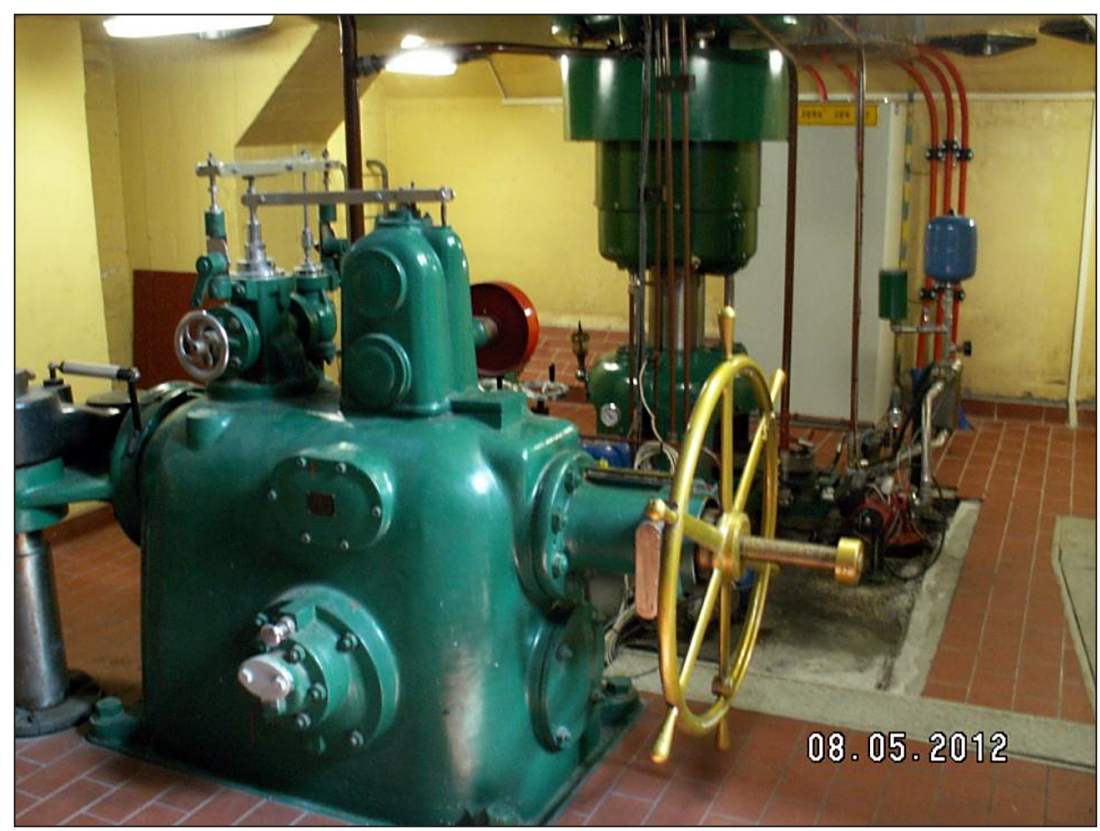

Figure 4. Hydraulic power plant Podgaje (photo by Authors) 


\section{Variant 3 of the analysis - Dobrygość weir}

Dobrygość weir is located at $\mathrm{km} 140+100$ of Prosna River. In the location of the weir, the river bed is shaped regularly. The banks of Prosna River in this area are covered by low vegetation, grass and bushes. The river bed is formed mainly from fine and medium sand. The weir is a concrete and reinforced concrete structure that belongs to the $4^{\text {th }}$ class of structures. The analysed hydraulic structure has three spans. It was constructed in 1973 (Figure 5). The weir is owned by the State Treasury and managed by the Regional Water Management Authority in Poznan. It was constructed as part of the project of regulating the Prosna river. Its task was to spate the water in order to provide water supply for capillary irrigation of meadows located along the river banks in the backwater section reaching from the Dobrygość weir to the Mieleszyn weir. Currently the aim of damming the waters of Prosna by the Dobrygość weir is to enable its use for supplying water to the LZD Siemianice ponds.

The $10.76 \mathrm{~m}$ wide span of the weir is divided by two reinforced concrete pillars, rounded on the upstream side, of a width of $0.7 \mathrm{~m}$ and a length of $2.5 \mathrm{~m}$. The weir has 3 spans, each $3.12 \mathrm{~m}$ wide. The structure is closed by manually operated double-partition sliders. The closure is sealed at the bottom with timber beams (Figure 5). On the upstream side, the Dobrygość weir is secured by two concrete plates of a total length of $4.5 \mathrm{~m}$. On the downstream side, there is a $10.2 \mathrm{~m}$ long and $10.76 \mathrm{~m}$ wide stilling ba$\sin$. Below it, the river bottom is reinforced with a $3 \mathrm{~m}$ long concrete plate and $6 \mathrm{~m}$ long stone riprap. Slopes behind the stilling basin are reinforced with three concrete plates, each $3 \mathrm{~m}$ long [Chudzińska 2009].

\section{RESULTS}

In order to select the most beneficial variant of the barrage, the evaluation of the influence of hydraulic structures was conducted according to the determined scenarios:

- scenario 1: weir + fish pass + hydraulic power plant,

- scenario 2: weir + hydraulic power plant,

- scenario 3: weir.

Basing on the separated factors, a hierarchic model was created (Figure 6). The model structure was developed in compliance with the principles of creating the so-called hierarchical structures with the influence scale [Saaty 2004, Wota 2005]. Tier I consists of one element, which is the objective of the task, i.e. the selection of the optimal variant of barrage. On the second tier a group of generally significant criteria was adopted. This group includes atmosphere, hydrosphere, biosphere, lithosphere and natural threats to the environment. On tier III of the model so-called sub-criteria were determined, as a more detailed elaboration of each of the main criteria. Within the "atmosphere" area, climate was defined as a sub-criterion, sub-criteria for "hydrosphere" were surface waters, ground waters and sediment. In the biosphere area flora and fauna were evaluated. The factors considered in the lithosphere area were land use, soils and landscape. The last crite-

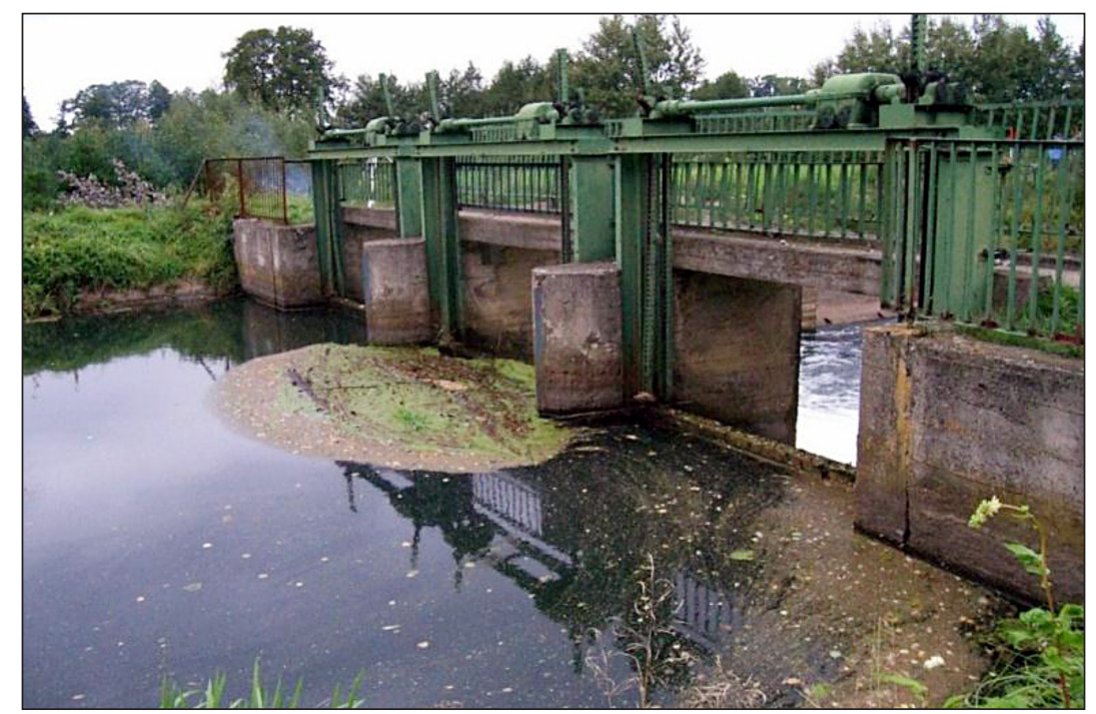

Figure 5. Dobrygość weir on the Prosna river, upstream view (photo by Authors) 
rion, natural hazards, was evaluated with respect to floods, flooding and landslides. On tier IV each of the implemented sub-criteria was assigned a numerical range, whose elements describe the degree of impact of the specific sub-criteria on the considered variants. The last tier of the model, i.e. the basis of hierarchy, is represented by alternative variants.

The hierarchical structure presented in figure 6 constituted the basis for analytic calculations, i.e. for the evaluation of the significance of all its components. The significance evaluation was expressed in a form of weights or priorities. The evaluation was conducted basing on authors' knowledge (the authors were considered experts) and on information provided by local and international subject literature. For each factor, local and global weights (preferences) were calculated. In order to evaluate the importance of elements, matrices were created for paired comparisons of the selected factors of the given tier with respect to the above tier. The evaluation scale was adopted according to Table 1. Elements located on Tier II of the hierarchy were evaluated in the aspect of their influence on the above element, i.e. the optimal variant of barrage. $M_{1} I I$ matrix of the size $(5 \times 5)$ created as a result of paired comparisons of Tier II criteria with respect to Tier I was solved. On Tier III of the hierarchy five matrices of the dimensions: $1 \times 1,3 \times 3,2 \times 2,3 \times 3,2 \times 2$ were solved. Tier IV required the evaluation of 11 matrices.
The sample process of obtaining criteria weights is presented in Tables 3 and 4. They contain the averaged results of paired comparisons of Tier II criteria and answers to the question which of the environmental elements are prone to the strongest influence of the barrage and what the extent of such influence is. Weights for lower tiers of the hierarchy were obtained in a similar way. When analysing the influence of barrages on specific environmental factors, one should first of all consider the criteria in tier II. Among the five separated groups, biosphere is the most vulnerable to influence (weight 0.264 ), followed by natural hazards (weight: 0.256 ), hydrosphere (weight: 0.229), lithosphere (weight: 0.189). The lowest significance refers to atmosphere (weight:

Table 3. Paired comparison of variables with respect to the environmental impact of the barrage

\begin{tabular}{|l|l|c|c|l|}
\hline \multicolumn{2}{|l|}{ Variable } & $\begin{array}{c}\text { Result of paired } \\
\text { comparison }\end{array}$ & \multicolumn{2}{c|}{ Variable } \\
\hline C1 & atmosphere & -3.5 & C2 & hydrosphere \\
\hline C1 & atmosphere & -3.5 & C3 & biosphere \\
\hline C1 & atmosphere & -4 & C4 & lithosphere \\
\hline C1 & atmosphere & -4 & C5 & natural hazards \\
\hline C2 & hydrosphere & 1 & C3 & biosphere \\
\hline C2 & hydrosphere & 1 & C4 & lithosphere \\
\hline C2 & hydrosphere & 1 & C5 & natural hazards \\
\hline C3 & biosphere & 2 & C4 & lithosphere \\
\hline C3 & biosphere & 1 & C5 & natural hazards \\
\hline C4 & lithosphere & -1.5 & C5 & natural hazards \\
\hline
\end{tabular}

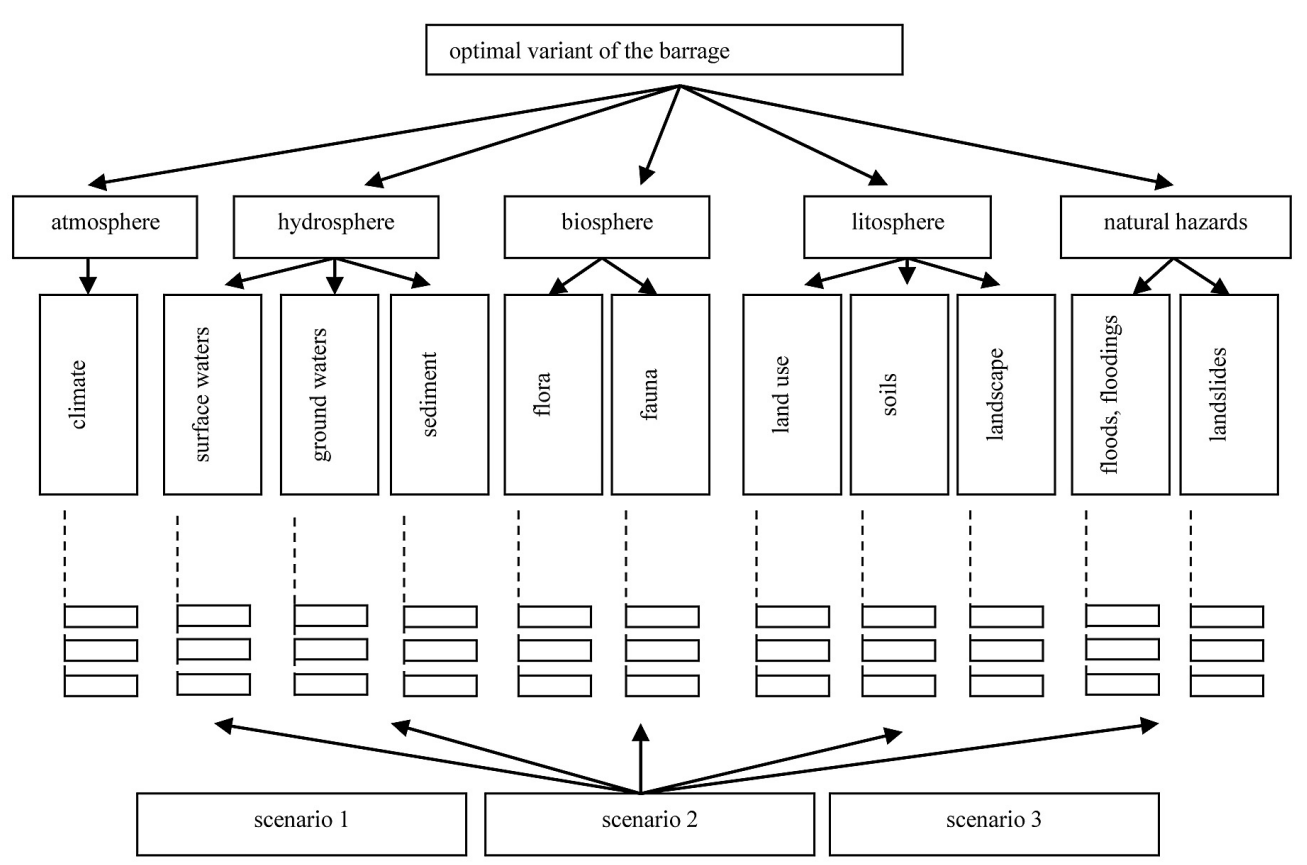

Figure 6. Hierarchical structure of the model (developed by Authors) 
Table 4. M II matrix of paired comparisons of criteria with respect to Tier I

\begin{tabular}{|c|c|c|c|c|c|c|c|}
\hline \multicolumn{2}{|r|}{ Variable } & $\mathrm{C} 1$ & $\mathrm{C} 2$ & $\mathrm{C} 3$ & $\mathrm{C} 4$ & $\mathrm{C} 5$ & wi - eigenvector \\
\hline C1 & Atmosphere & 1 & 0.3 & 0.3 & 0.3 & 0.3 & 0.062 \\
\hline $\mathrm{C} 2$ & Hydrosphere & 3.5 & 1 & 1 & 1 & 1 & 0.229 \\
\hline C3 & Biosphere & 3.5 & 1 & 1 & 2 & 1 & 0.264 \\
\hline $\mathrm{C} 4$ & Lithosphere & 4 & 1 & 0.5 & 1 & 0.7 & 0.189 \\
\hline C5 & Natural hazards & 4 & 1 & 1 & 1.5 & 1 & 0.256 \\
\hline \multicolumn{7}{|c|}{$\lambda_{\max }=5.07 ; \mathrm{Cl}=0.01 ; \mathrm{IR}=0.01 ; \mathrm{RI}=1.12$} & Total $=1$ \\
\hline
\end{tabular}

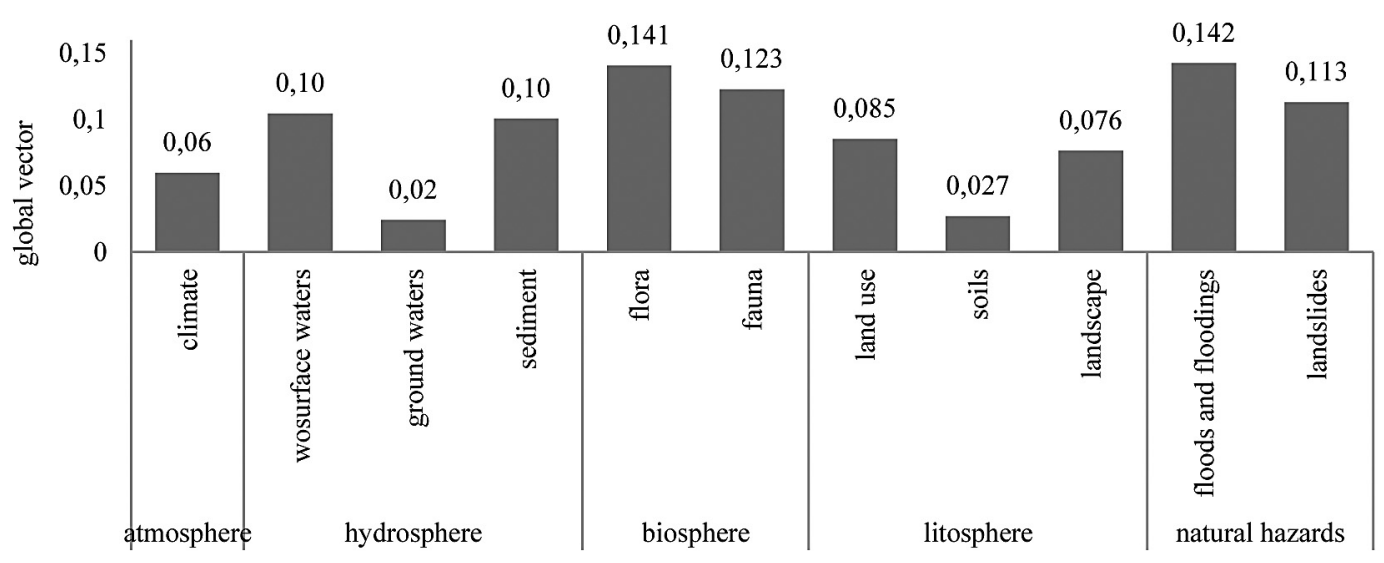

Figure 7. Global preferences of Tier III sub-criteria (developed by Authors)

0.062). In the case of tier III factors the threat of floods and flooding has the highest significance for impact evaluation, and thus for the selection of the optimal variant (weight: 0.0142 , followed by the influence on flora (weight: 0.141). The least significant is the influence on ground waters (weight: 0.02) and soils (weight: 0.027). Results of this part of calculations are presented in Figure 7.

Final overall weights calculated for the assumed scenarios were used to order them according to their environmental impact. Thus, they gave an answer to the question concerning the selection of the optimal variant of barrage in the aspect of the lowest environmental impact. Ranking the selected scenarios according to overall preferences it is stated that the lowest environmental impact was demonstrated by scenario 3 (resulting vector: 0.22 ), followed by scenario 2 (resulting vector: 0.33 ). Scenario 1 is characterised by the strongest influence on the evaluated elements of the environment.

\section{CONCLUSIONS}

The multicriteria model with a scale of influence presented in this study is a universal model that can easily be applied to the evaluation of the impact of hydrotechnical structures. New ele- ments as well as opinions and the modifications of the number of experts may be easily incorporated into the model. A great advantage of the presented methodology is the simplicity of its application, relatively low financial costs and the possibility to use wide knowledge available in various data sources.

In the practical aspect, the application of the described methodology may constitute a perfect tool for making decisions concerning water management. The application of the AHP method may also provide support in the preparation of reports on the environmental impact of a given enterprise and it may be used as justification of the proposed variant of the enterprise.

\section{REFERENCES}

1. Adamus W., Łasak P., 2010. Zastosowanie metody AHP do wyboru umiejscowienia nadzoru nad rynkiem finansowym. Bank i Kredyt 41 (4), 73-100.

2. Chudzińska N. 2009. Analiza procesu erozji dennej poniżej jazów piętrzących na wybranym odcinku rzeki Prosny. Praca magisterska, maszynopis

3. Downarowicz O., Krause J., Sikorski M., Stachowski W., 2000. Zastosowanie metody AHP do oceny i sterowania poziomem bezpieczeństwa złożonego obiektu technicznego. Politechnika Gdańska, Wydział Zarządzania i Ekonomi, 7-42. 
4. Fabisiak L. Ziemba P., 2011. Wybrane metody analizy wielokryterialnej $\mathrm{w}$ ocenie użyteczności serwisów internetowych. Zesz. Nauk. Uniwersytetu Szczecińskiego, Studia Informatica, 28(656), 21-33.

5. Franczak D. 2009. Odbudowa jazu Skórka, gm. Krajenka, pow. złotowski. Operat wodno prawny. Maszynopis. Biuro studiów i proj. bud. wod. „Hydroprojekt", Poznań.

6. Kubiak-Wójcicka K., Muszyńska J. 2011. Wykorzystanie odnawialnych źródeł energii do produkcji energii elektrycznej na przykładzie EW Podgaje. Gaz, Woda i Technika Sanitarna, 10, 371-373.

7. Saaty T.L., 2004. Decision making the Analityc Hierarchy and Network Processes (AHP/ANP). Journal of Systems Science and Systems Engineering 13(1), 1-35.
8. Skorupka D., Duchaczek A., 2010. Zastosowanie metody AHP w optymalizacji procesów decyzyjnych związanych z realizacją przedsięwzięć logistycznych. Zeszyty Naukowe WSOWL, 3(157). 54-62.

9. Sterpejkowicz-Wersocki W., Bolt A. 2002. Jazy lewarowe na rzece Gwdzie. Inżynieria Morska i Geotechnika, 23(3), 162-165.

10. Tułecki A. Król S., 2007. Modele decyzyjne z wykorzystaniem metody Analytic Hierarchy Process (AHP) w obszarze transportu. Problemy Eksploatacji, 2, 171-180.

11. Wota A.K., 2005. Możliwość zastosowania metody AHP do oceny przydatności terenów problemowych dla rolnictwa. Acta Agraria et Silvestria. Sekcja Ekonomiczna, vol. XLIV/1, 409-416. 